\title{
Pengembangan Sistem Pembimbing Akademik Secara Online Dengan Memanfaatkan Teknologi Rich Internet Application
}

\section{System Development Academic Guide Online Using Technology Rich Internet Application}

\author{
Delpiah Wahyuningsih \\ Jurusan Teknik Informatika, STMIK Atma Luhur Pangkalpinang \\ Jln Jend Sudirman Selindung Kec Gabek Pangkalpinang \\ delphibabel@atmaluhur.ac.id
}

\begin{abstract}
Abstrak
Bimbingan Akademik yang terjadi pada STMIK Atma Luhur saat ini ada tetapi manual dan tidak terkontrol. Kegiatan pembimbing akademik hanya untuk mengentri kartu rencana studi mahasiswa setiap semester, konsultasi KRS yang akan di ambil mahasiswa dan konsultasi masalah yang lainnya dipegang oleh mahasiswa yang bersangkutan sedangkan dosen pembimbing akademik tidak memegang rekap konsultasi bimbingan akademik dan jika ditanyakan kepada dosen pembimbing akademik masing-masing. Kadang mereka kehilangan daftar mahasiswa yang harus di konsultasi. Sistem pembimbing akademik yang berbasis website ini bertujuan untuk mengontrol mahasiswa yang di PA oleh dosen masing-masing dan data mahasiswa yang bimbingan terkontrol serta histori mahasiswa yang sudah bimbingan kepada dosen pembimbing akademik serta dosen pembimbing akademik dapat mencetak sewaktu-waktu data list mahasiswa yang bimbingan. Sistem PA ini dengan terapan teknologi Rich Internet Application (RIA) yang mempunyai karakteristik yaitu responsif dan interaktif. Penerapan rich internet application pada sistem pembimbing akademik yang berbasis website ini mampu berinteraksi dengan mahasiswa yang dibimbing dimanapun berada dengan karakteristik dari rich internet application yang interaktif dan responsif. Karakteristik RIA yang Interaktif pada sistem ini tersedia chat. Dimana memudahkan mahasiswa dan dosen pembimbing akademik untuk konsultasi. Sedangkan karakteristik responsif terdapat pada setiap link pada sistem, terutama pada form bimbingan. hasil responden terhadap user atau dosen PA pada pengembangan sistem penasehat akademik secara online secara keseluruhan menyatakan $26,668 \%$ sangat setuju dan 71,666\% menyatakan setuju.
\end{abstract}

Kata Kunci- rich internet application, pembimbing akademik, konsultasi pembimbing akademik

\section{Abstract}

Academic Guidance happened to STMIK Atma Luhur currently exist but the manual and uncontrolled. Activity counselors only for mengentri card study plan students every semester, consultation KRS which will take students and consulting other problems held by the student while the supervisor of academic not hold recap consulting academic guidance and if asked the supervisor of academic respectively, Sometimes they lose the list of students who should be in consultation. System counselors based this website is intended to control the students in the PA by lecturers each and the student data is guidance control as well as a history student who had guidance to the supervisor of academic and faculty counselors can print at any time data list student guidance. The PA system with applied technologies of Rich Internet Application (RIA) that have characteristics that is responsive and interactive. Adoption of rich Internet applications on the system of academic counselors based website is able to 
interact with students everywhere are guided by the characteristics of rich Internet applications, interactive and responsive. Characteristics of the Interactive RIA on this system is available chat. Where facilitate student and faculty academic supervisor for consultation. While responsive characteristics contained in each link in the system, especially in the form of guidance. The results of respondents to users or lecturers $P A$ on the development of online academic advisory system as a whole states $26.668 \%$ strongly agree and $71.666 \%$ agreed

Kata Kunci-rich Internet applications, academic supervisor, website

\section{PENDAHULUAN}

Saat ini berkembangnya teknologi di segala bidang, yang telah merambah keseluruh kalangan baik kalangan pemerintahan maupun swasta. Terutama sistem pada website dengan berbagai macam bahasa pemrograman, framework dan lain-lain. Baik dalam hal untuk kodingan maupun dalam tampilan website itu sendiri.

Sama halnya sistem berbasis website pada salah satu perguruan tinggi yaitu STMIK Atma Luhur yang sangat membutuhkan sistem berbasis website. STMIK Atma Luhur Pangkalpinang saat ini memerlukan sebuah sistem yang dapat memperlancar proses bisnis dalam kegiatan atau aktivitas mahasiswa, dosen, pegawai serta pihak yayasan. Salah satu sistem tersebut yaitu sistem bimbingan akademik atau yang sering kita sebut Pembimbing Akademik (PA).

Proses bisnis pada pembimbing akademik yang terjadi saat ini di STMIK Atma Luhur Pangkalpinang kurang terkontrolnya mahasiswa yang di bimbing. Contohnya dosen yang tidak menyimpan histori mahasiswa yang telah di bimbing oleh masing-masing PA. dan mahasiswa hanya datang konsultasi ke pembimbing akademik, catatan hanya diberikan kepada mahasiswa. Dosen PA tidak menyimpan salinan yang telah di konsultasikan tersebut. Kadang kala nama mahasiswa yang di bimbing oleh dosen PA tidak terkontrol. Ada sebagian dosen PA lupa daftar mahasiswa yang di bimbing, dan dosen tersebut meminta kepada program studi masing-masing untuk mengetahui siapa saja mahasiswa yang dibimbing dengan meminta data perangkatan.

Dengan masalah yang terjadi pada STMIK Atma Luhur maka perlu adanya sistem pembimbing akademik yang berbasis website. Disini sistem pembimbing akademik dapat mengontrol daftar mahasiswa yang akan di bimbing, histori mahasiswa yang bimbingan juga terdata secara rinci dan detail. Dengan pemanfaatan teknologi Rich Internet Application (RIA) sangan membantu sebuah sistem pembimbing akademik. Dimana teknologi Rich Internet Application (RIA) merupakan merupakan aplikasi web yang memiliki fitur dan fungsi seperti aplikasi desktop, RIA dapat berjalan pada web browser biasa tanpa harus memerlukan software tertentu [1].

Penelitian yang terkait dengan teknologi Rich Internet Application yaitu pertama penelitian dari [1] Delpiah Wahyuningsih dan Yohanes, yang berjudul "penerapan teknologi rich internet application pada proses tracer alumni STMIK Atma Luhur Berbasis Website" yang menghasilkan sistem pendataan alumni dapat mempermudah dalam mengisi data terbaru, melihat informasi lowongan pekerjaan dan pelatihan serta sistem pendaatan alumni dapat mempermudah bagian kemahasiswaan dalam memperoleh data alumni secara up to date. Kedua penelitian dari [2] Fiftin Noviyanto dan Ahmad Ashari yang berjudul "penerapan teknologi RIA untuk membangun aplikasi web dengan pengaksesan realtime (studi kasus. Pemesanan handphone online)" yang menghasilkan aplikasi web yang dikembangkan dengan teknologi RIA memiliki kelebihan pada rata-rata kecepatan akses lebih tinggi dibanding teknologi tanpa RIA. Ketiga penelitian dari [3] Eggy Ramadhani Djunaedi yang berjudul "konsep rancang bangun aplikasi e-traveling Berbasis Customer Relationship Management menggunakan Rich Internet Application" yang menghasilkan RIA dapat mempermudah dalam pencarian dadta dengan sumber yang lebih luas yaitu internet tanpa harus memasukkan data tersebut ke dalam memori web e-travel. Sehingga penggunaan RIA pada web akan meringankan proses web dalam penyediaan data. Keempat penelitian dari [4] Fiftin Noviyanto dan Danang Dwi Wahyu Jati yang berjudul "Rich Internet Application (RIA) untuk Aplikasi Sistem Informasi Klinik 
Kesehatan" yang menghasilkan Rich Internet Application merupakan aplikasi yang memadukan fungsionalitas aplikasi desktop dan web, flash merupakan salah satu aplikasi yang mampu digunakan utnuk membuat aplikasi RIA dengan perpaduan antara actionscript dan PHP, untuk menghubungkan agar perintah PHP dapat diterima oleh Flash, perlu dilakukan beberapa penyesuaian perintah. Kelima penelitian dari [5] Mochamad Samsudin Imron, dkk yang berjudul Perancangan dan Implementasi Aplikasi Pembelajaran Siklus Carnot Berbasis RIA untuk Pelajar SMA. yang menghasilkan aplikasi pembelajaran siklus carnot berbasis RIA untuk pelajar SMA dapat membantu pengguna dalam hal ini siswa untuk memahami materi siklus carnot dengan melihat dan mengikuti materi dan animasi yang diberikan, membantu siswa mengetahui hasil belajar dengan melihat dan mengikuti evaluasi berdasarkan materi yang diberikan. Hal ini dapat dibuktikan dengan hasil pengujian manfaat oleh pengguna menganggap bahwa aplikasi pembelajaran siklus carnot berbasis RIA sudah berjalan dengan baik dan dapat membantu siswa dalam memahami materi. Keenam penelitian dari [6] Yessy Asri dan Anggi Puspita Sari yang berjudul Implementasi Teknologi RIA dalam Pengembangan Antar Muka berbasis Web menggunakan EXT JS Frame Work. Yang menghasilkan Framework ext js digunakan untuk membantu UI aplikasi web menjadi seperti aplikasi desktop dan memudahkan dalam membangun sebuah UI. Pada perancangan guna membangun UI dengan framework ext js yaitu menentukan kebutuhan user yang berorientasi pada tugas yang dikerjakan dan menentukan paket-paket serta kelas-kelas yang akan digunakan.

\section{METODE PENELITIAN}

\subsection{Rich Internet Application (RIA)}

Rich Internet Application (RIA), merupakan aplikasi web yang memiliki fitur dan fungsi seperti aplikasi desktop, RIA dapat berjalan pada web browser biasa tanpa harus memerlukan software tertentu. [7]

Kelebihan RIA dibandingkan Web Statis. Aplikasi web statis adalah web yang tampilan user interfacenya hanya dihasilkan dari kode-kode HTML saja. Untuk aplikasi web yang dibangun dengan menerapkan teknologi RIA memiliki kelebihan-kelebihan diantaranya:

a. Richer

RIA tidak hanya menawarkan halaman antarmuka yang dihasilkan dari file html, tetapi dengan fungsi ini, maka dapat memasukkan sesuatu yang dapat diimplementasikan pada teknologi yang digunakan pada sisi client, seperti drag dan drop, menggunakan slider untuk mengubah data, perhitungan dapat dilakukan di computer client.

b. Responsif

Membuat respon halaman web lebih cepat dengan cara tidak merubah (me-load) seluruh halaman web, tetapi hanya sebagian kecil dari informasi yang diperlukan saja.

c. Komunikasi Asychronous

Saat user pertama kali melakukan aktifitas di client maka client mengirimkan request kepada server dan server akan memberikan respon dari hasil request yang sudah dikirimkan oleh client. Selama proses tersebut interface pada client tidak ada pengaruh sama sekali. Ketika melakukan aktifitas selanjutnya client hanya mengirimkan request yang dibutuhkan saja, karena request-request yang sudah dikirimkan pada aktifitas pertama kali, disimpan dalam engine sementara. Hal ini menyebabkan client tidak sepenuhnya bergantung dengan server.

\subsection{Web Engineering}

Metode yang digunakan untuk membangun sistem ini dengan web engineering. Web engineering adalah suatu proses yang digunakan untuk menciptakan suatu sistem aplikasi berbasis yang berkualitas tinggi. Berikut tahapan dari web engineering:

a. Formulation (Definisi Masalah)

Merupakan kegiatan yang bertujuan untuk merumuskan tujuan dan aplikasi berbasis web serta menentukan bahasan sistem. Memungkinkan pelanggan dan pengembang untuk 
mendirikan suatu set tujuan umum dan sasaran untuk membangun dan juga mengidentifikasi web itu sendiri.

Setelah melakukan tahap perumusan masalah, langkah selanjutnya adalah menentukan solusi yaitu membangun sistem.

b. Analysis (Analisis)

Pada tahap ini dilakukan analisa kebutuhan dan spesifikasi lengkap tentang isi, jenis skrip yang digunakan, menentukan web statis atau dinamis, penggunaan multimedia dan kebutuhan-kebutuhan lainnya. Pada tahap ini harus menerangkan sejelas-jelasnya terhadap situs web yang akan dibangun, alat dan bahan yang akan digunakan.

c. Design (Perancangan)

Tahap perancangan adalah untuk merancang, menghasilkan, dan memperoleh semua teks, grafik, audio, video yang akan disatukan ke dalam aplikasi web.

d. Testing (Pengujian)

Pada tahap ini dilakukan pengujian terhadap program. Kegiatan ini dilakukan untuk mewujudkan desain menjadi website dan menguji apikasi berbasis web yang telah selesai dibuat. Proses pengujian berfokus pada logika internal software untuk memastikan bahwa semua pernyataan sudah diuji serta pada fungsi eksternal yaitu, mengarahkan pengujian untuk menemukan kesalahan-kesalahan dan memastikan bahwa dengan input yang terbatas akan didapatkan hasil yang sesuai dengan yang dibutuhkan. [8]

\subsection{Sistem yang berjalan saat ini}

Sistem pembimbing akademik saat ini pada STMIK Atma Luhur yaitu mahasiswa pada semester pertama menuju semester dua akan diberikan dosen pembimbing akademik yang datanya akan ditempel pada papan pengumuman, melalui website Atma Luhur, dan melalui sosial media yaitu grup facebook Atma Luhur. Dosen diberikan SK yang diberi tugaskan dan tanggungjawab untuk membimbing mahasiswa secara akademik maupun non akademik untuk konsultasi mengenai apapun terutama menyangkut proses akademik. Pada SK yang diberikan tersebut tercantum nama mahasiswa-mahasiswa yang akan di bimbing. Dosen pembimbing akademik mempunyai kewajiban untuk mengikuti proses dari awal perkuliahan semester satu sampai mahasiswa tersebut selesai dari kalangan institusi STMIK Atma Luhur., itu secara teoritisnya tetapi yang terjadi dilapangan saat ini yaitu secara garis besar dimana mahasiswa yang melakukan bimbingan hanya saat pengisian kartu rencana studi (KRS) untuk melanjutkan ke semester berikutnya. Kebanyakan mahasiswa bimbingan yang lainnya ke program studi masing-masing dan ada beberapa mahasiswa yang sulit untuk menemui dosen pembimbing akademik contohnya dalam bimbingan untuk pengambilan matakuliah untuk semester berikutnya atau untuk pengisian KRS.

Bimbingan tersebut seharusnya melalui dosen pembimbing akademik masing-masing yang telah ditentukan tetapi dengan sulitnya ditemui, mahasiswa mengisi krs ke prodi dan kadangkala dalam satu semester tersebut mahasiswa tidak menemui pembimbing akademik. Mahasiswa langsung menemui prodi masing-masing untuk pengisian krs atau hal lainnya. Hal ini bimbingan mahasiswa seharusnya terekam di dosen pembimbing masing-masing. Sama halnya dengan dosen pembimbing akademik, kadang mereka lupa mencatat/mendokumentasikan bimbingan mahasiswa yang telah di bimbing dan sering terjadi dosen lupa siapa saja mahasiswa yang harus di bimbing.

\subsection{Usecase Diagram}

Usecase diagram merupakan sistem yang diajukan dengan penerapan Rich Internet Application. 


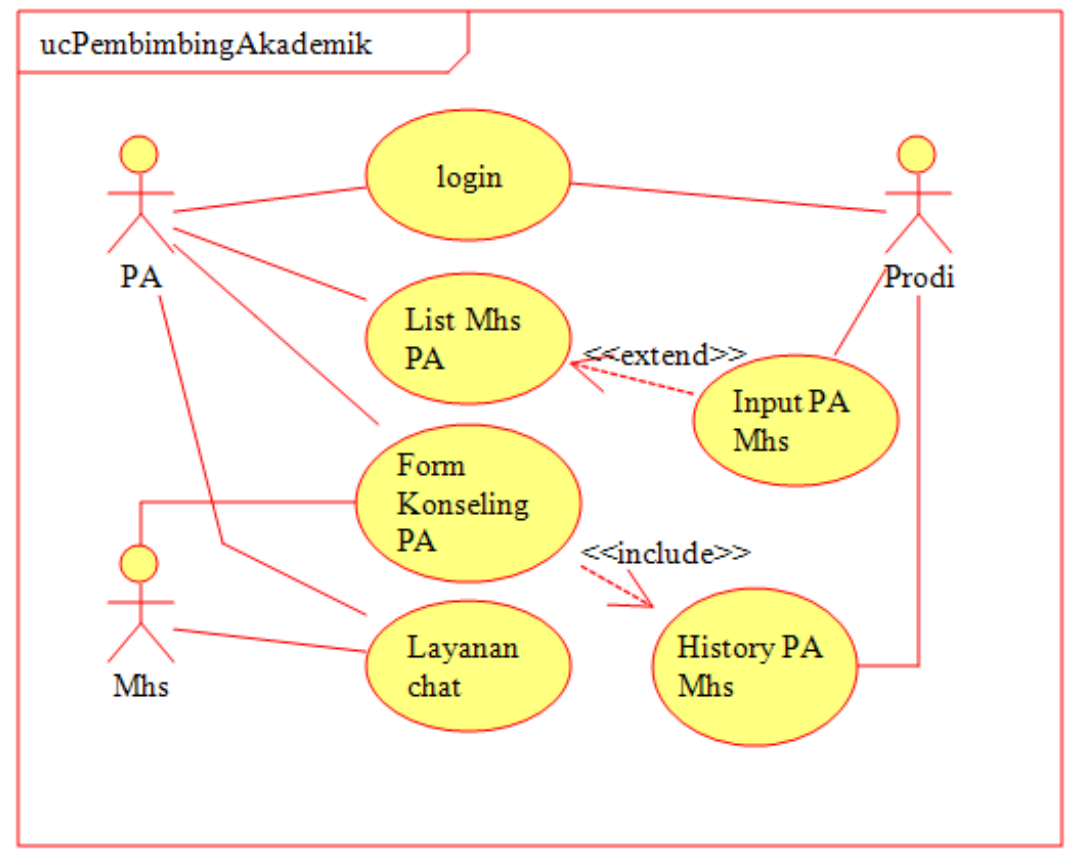

Gambar 1. Sistem yang diajukan

Penjelasan dari gambar 1 yaitu dimana pertama bagian progam studi (ketua program studi atau sekretaris program studi) memasukkan data mahasiswa yang akan di bimbing oleh masing-masing pembimbing akademik (PA) disini bagian prodi yang menginput data melalui desktop yang disimpan ke server. Kedua data yang telah tersimpan di server, dikelola dan di transfer ke client yang akan ditampilkan melalui website pembimbing akademik. PA dapat melihat daftar atau list mahasiswa yang akan di bimbing. PA mengisi form konseling ketika mahasiswa bimbingan. Apapun yang dibimbing akan terdata di history mahasiswa bimbingan. History mahasiswa yang bimbingan dapat dilihat dan dicetak oleh PA masing-masing dan prodi. Di website pembimbing akademik ini menyediakan layanan obrolan untuk mahasiswa dan pembimbing akademik.

\section{HASIL DAN PEMBAHASAN}

Hasil pengembangan sistem ini merupakan penggabungan antara sistem lama (sistem pembagian PA berbasis desktop yang sudah ada saat ini pada STMIK Atma Luhur) dengan sistem baru yaitu sistem pembimbing akademik berbasis online dimana antara dosen dan mahasiswa bisa saling interaksi dengan mudah. Sistem online ini menyediakan list mahasiswa, form konseling, history konseling dan layanan obrolan antara mahasiswa dan dosen PA.

\subsection{Input Dosen Pembimbing Akademik Mahasiswa}

Input mahasiswa merupakan tampilan pada aplikasi desktop yang di input oleh program studi yaitu ketua program studi atau sekretaris program studi. Nama-nama mahasiswa yang dibimbing oleh dosen pembimbing akademik sesuai dengan home base masing-masing dosen dan mahasiswa. Tampilan input mahasiswa PA seperti berikut. 


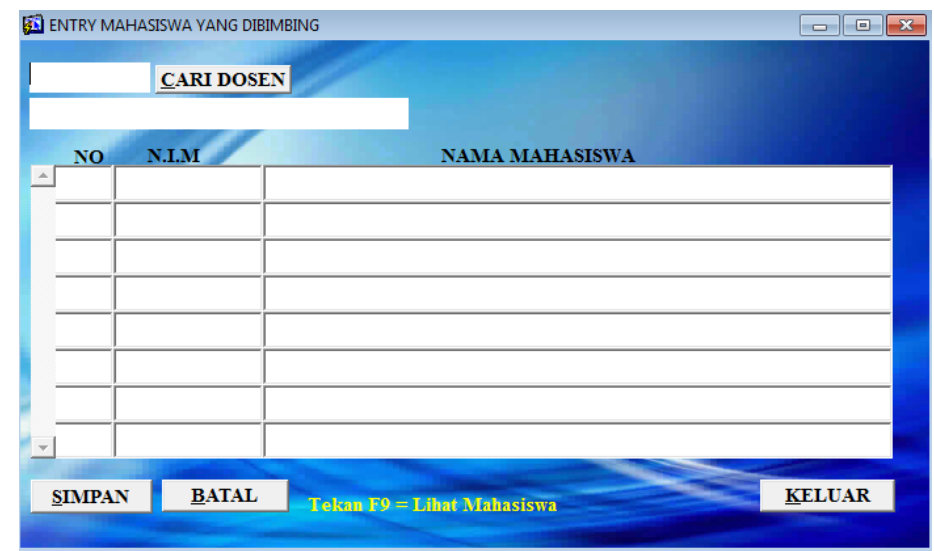

Gambar 2. Input Dosen Pembimbing Akademik Mahasiswa

Penjelasan dari gambar 2 yaitu dimana bagian program studi (ketua program studi atau sekretaris program studi) memasukkan data dosen pada kolom cari dosen, ketika di klik cari dosen maka akan tampil list seperti berikut.

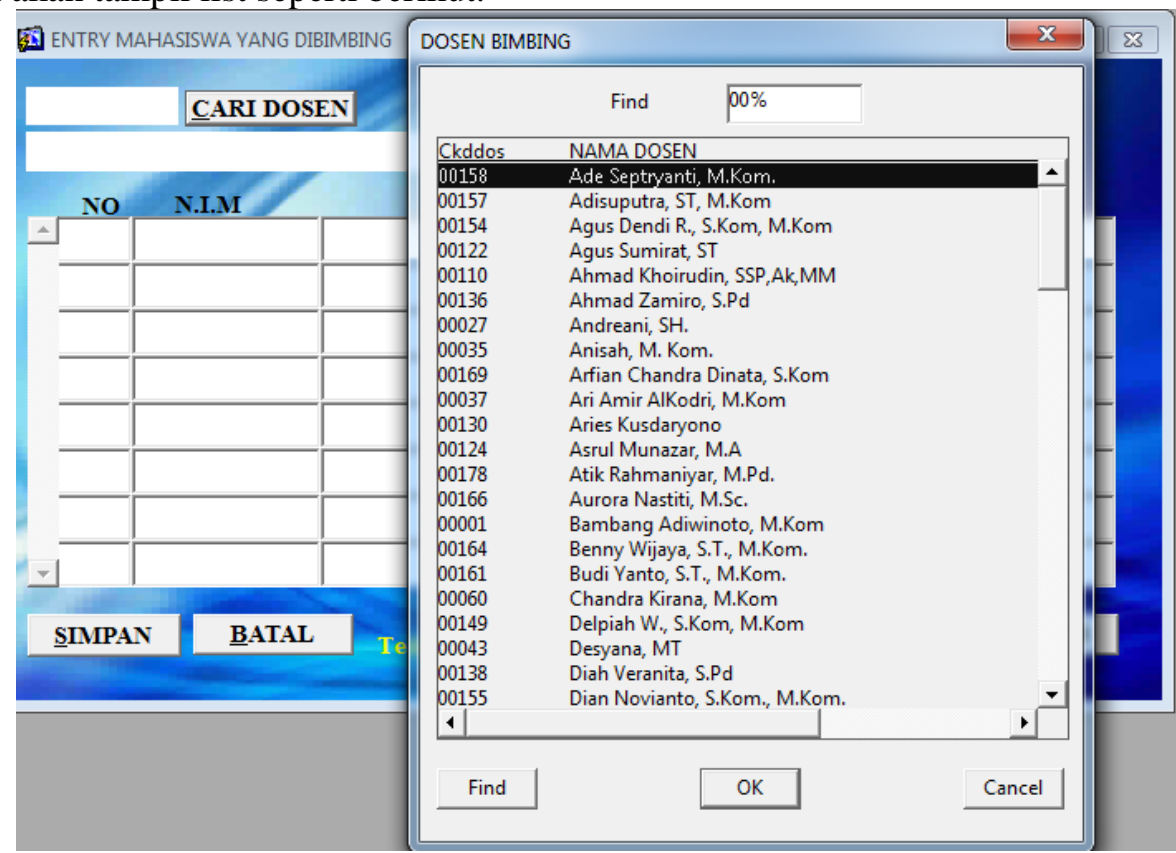

Gambar 4. Daftar Dosen

Setelah nama dosen dipilih maka bagian prodi memasukkan nama-nama mahasiswa yang akan di PA oleh dosen yang bersangkutan seperti gambar 4 di atas.

\subsection{List Mahasiswa PA}

List mahasiswa merupakan tampilan halaman pada website yang berfungsi untuk melihat nama mahasiswa yang di bimbing dari awal perkuliahan sampai akhir perkuliahan di Atma Luhur yang artinya dari semester satu sampai mahasiswa tersebut diwisudakan. Itu merupakan tanggungjawab pembimbing akademik. Halaman list mahasiswa ini dapat dilihat dan juga dicetak. Tampilan list mahasiswa seperti gambar 5 berikut ini. 


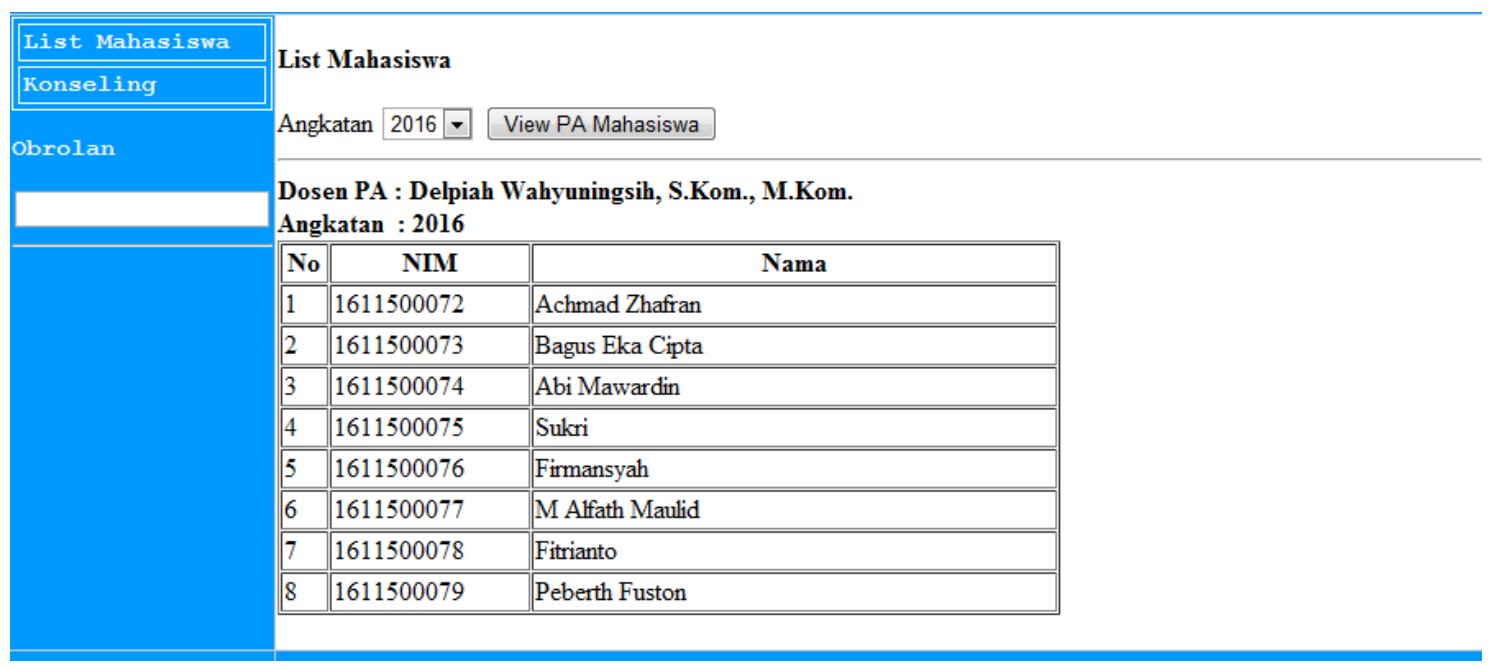

Gambar 5. List Mahasiswa

\subsection{Form Konseling PA}

Form konseling merupakan tampilan halaman pada website dosen PA yang di isi oleh dosen PA ketika mahasiswa bimbingan, baik bimbingan akademik maupun non akademik. Form konseling terbagi beberapa yaitu perkembangan prestasi akademik dan kegiatan konseling Tampilan form konseling perkembangan prestasi seperti gambar 6 berikut ini.

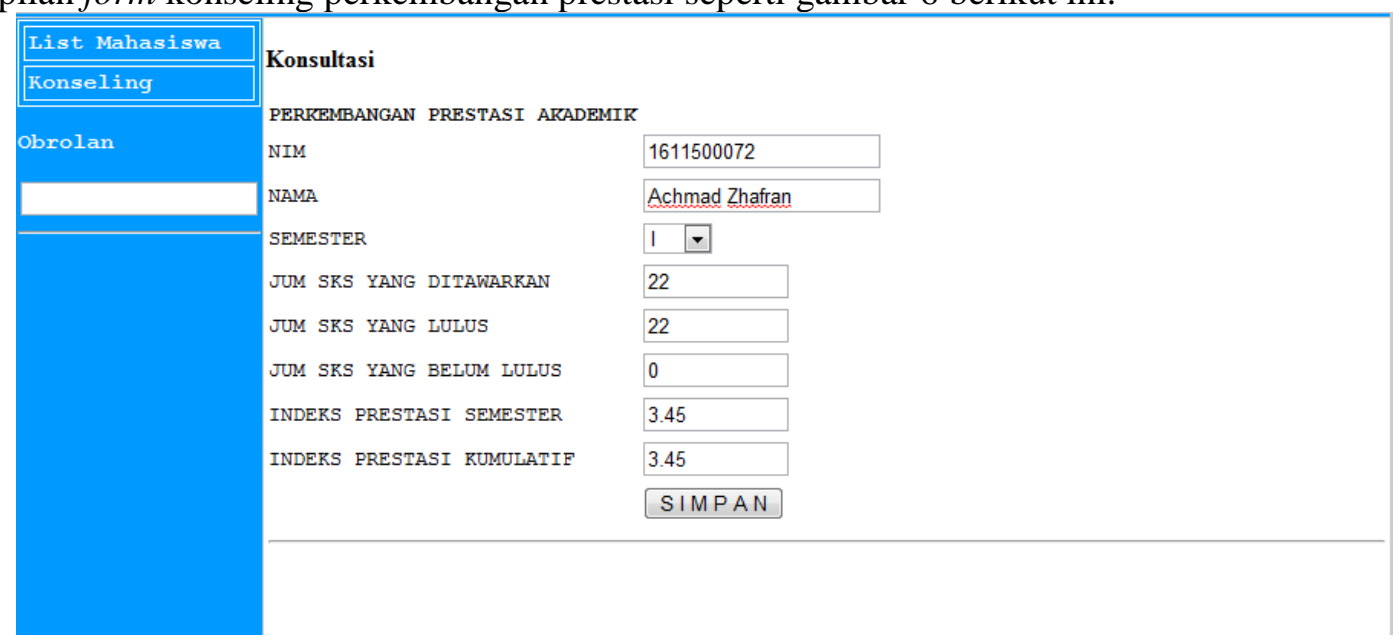

Gambar 6. Form Konseling perkembangan prestasi akademik

Penjelasan dari gambar 6 berfungsi dimana dosen PA mengisi data perkembangan prestasi akademik mahasiswa kemudian data tersebut disimpan keserver. Semua yang di konseling direkam melalui sistem pembimbing akademik. Rekaman ini dapat dilihat oleh dosen PA masing-masing dan prodi. Nama rekaman ini yaitu history mahasiswa dengan tampilan sebagai berikut.

Kemudian ketika mahasiswa konseling perkembangan prestasi, maka dosen pembimbing akademik mengisi pada form konseling kegiatan seperti gambar 7 berikut ini. 
Pengembangan Sistem Pembimbing Akademik Secara Online...

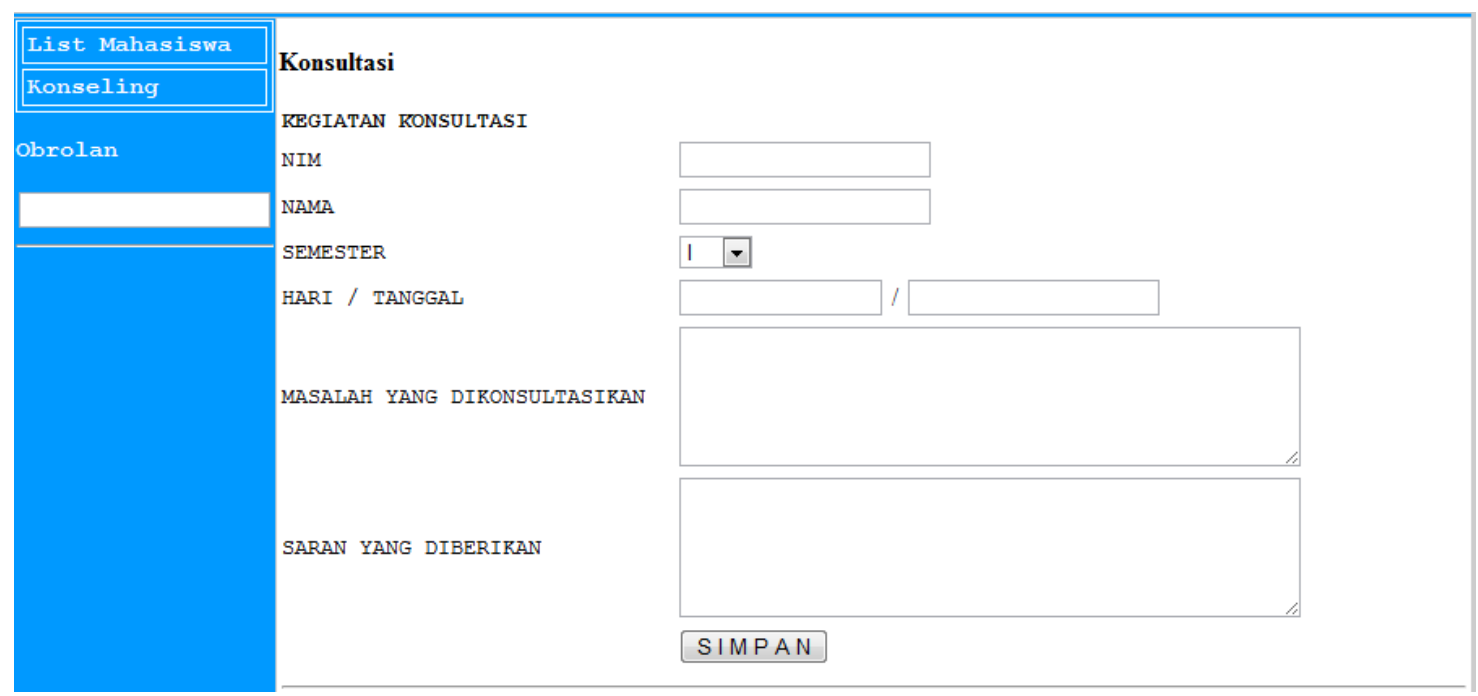

Gambar 7. Konsultasi Kegiatan

\subsection{History Konseling}

History konseling merupakan tampilan yang disediakan oleh sistem pembimbing akademik berbasis website ini untuk melihat semua data mahasiswa dari awal bimbingan sampai akhir bimbingan. Tampilan history konseling seperti gambar 8 berikut ini.

\begin{tabular}{|l|l|l|}
\hline \hline List Mahasiswa & \\
\hline Konseling & \\
\hline Obrolan & NIM 1611500072 & VIEW \& CETAK \\
\hline
\end{tabular}

Gambar 8. History Konseling

Penjelasan gambar history konseling yaitu jika dosen pembimbing akademik atau prodi ingin mengetahui history mahasiswa konseling maka masukkan nim mahasiswa kemudian akan tampil seperti gambar 9 berikut ini.

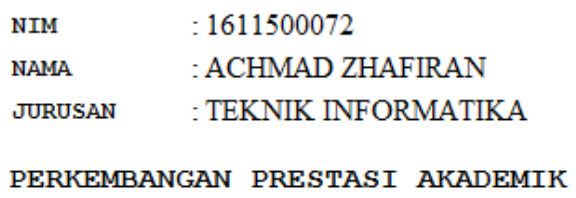

\begin{tabular}{|l|c|}
\hline SEMESTER & I \\
\hline SKS DITAWARKAN & 22 \\
\hline SKS LULUS & 22 \\
\hline SKS BELUM LULUS & 0 \\
\hline IPS & 3.45 \\
\hline IPK & 3.45 \\
\hline
\end{tabular}

KEGIATAN KONSELING

\begin{tabular}{|c|c|c|l|l|}
\hline NO & SEMESTER & HARI/TANGGAL & \multicolumn{1}{|c|}{ MASALAH } & BIMBINGAN \\
\hline 1 & $\mathrm{I}$ & $\mathrm{kamis} / 22-12-2016$ & Konsultasi KRS & ambil 22 sks \\
\hline
\end{tabular}

Gambar 9. History Konseling Mahasiswa 


\subsection{Layanan Obrolan}

Layanan obrolan merupakan tampilan yang disediakan oleh sistem pembimbing akademik berbasis website ini untuk dosen PA dan Mahasiswa. Tampilan layanan obrolan seperti gambar 10 berikut ini.

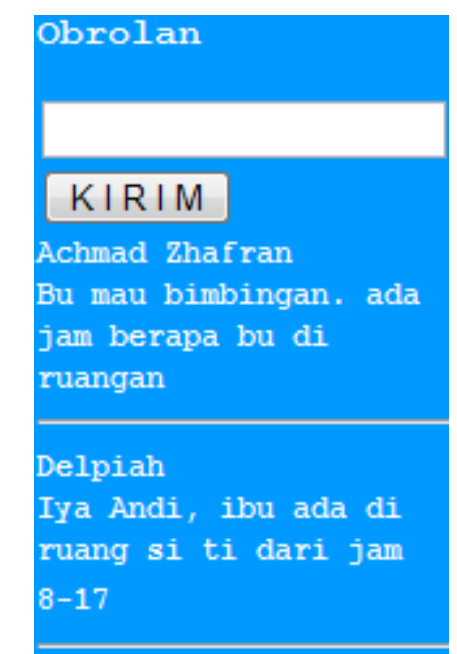

Gambar 10. Layanan Obrolan

\subsection{Analisis Value}

Analsis value menggunakan kuesioner disebarkan menggunakan teknik sampling yaitu simple random. Sampling digunakan disebarkan kepada 12 pengguna yaitu 3 user dosen PA jurusan Teknik Informatika, 3 user dosen PA Sistem Informasi dan 3 user dosen PA manajemen informatika. Dari hasil kuesioner tersebut akan dilakukan perhitungan agar dapat di ambil kesimpulan terhadap penilaian penerapan sistem. Kuesioner ini terdiri dari 5 pertanyaan dengan menggunakan skala likert dengan skala 1 sampai 4 (sangat setuju, setuju, tidak setuju dan sangat tidak setuju) dengan ketentuan skala untuk tiap pertanyaan sebagai berikut.

a. Sistem pengembangan pembimbing akademik secara online yang dibangun memudahkan konsultasi dengan mahasiswa?

b. Sistem pengembangan pembimbing akademik secara online mudah digunakan?

c. Form konseling sistem pengembangan pembimbing akademik secara online sudah memenuhi kebutuhan user?

d. Fitur obrolan sistem pengembangan pembimbing akademik secara online memudahkan dosen PA dengan mahasiswa dalam konseling?

e. Sistem pengembangan pembimbing akademik secara online lebih mudah digunakan dibandingkan sistem PA sebelumnya?

Berdasarkan hasil kuesioner yang dibagikan kepada 12 dosen PA yaitu hasil pertanyaan pertama sebanyak 4 orang atau 33,33\% yang menjawab sangat setuju dan 8 orang atau $66,67 \%$ menjawab setuju. hasil pertanyaan nomor dua dan tiga sebanyak 2 orang atau $16,67 \%$ yang menjawab sangat setujua dan 10 orang atau $83,33 \%$ menjawab setuju. hasil pertanyaan nomor empat, sebanyak 3 orang atau $25 \%$ yang menjawab sangat setuju, 8 orang atau $66,67 \%$ menjawab setuju dan 1 orang atau 8,33\% menjawab tidak setuju. Hasil pertanyaan nomor lima, sebanyak 5 orang atau $41,67 \%$ yang menjawab sangat setuju dan 7 orang atau 58,33\% menjawab setuju. 


\section{KESIMPULAN}

Kesimpulan dari sistem pembimbing akademik berbasis website ini yaitu:

a. Penerapan Rich Internet Application (RIA) memberikan kemudahan pada pengembangan sistem ini dengan fasilitas layanan obrolan antara Pembimbing akademik dan mahasiswa.

b. Ketika PA lupa nama-nama mahasiswa yang di bimbing maka PA dapat melihat list mahasiswa yang akan di bimbing melalui website sistem pembimbing akademik

c. Pembimbing akademik dan prodi dapat melihat history dan mencetak history dari mahasiswa yang bimbingan selama ini.

d. Hasil responden terhadap user atau dosen PA pada pengembangan sistem penasehat akademik secara online secara keseluruhan menyatakan $26,668 \%$ sangat setuju dan $71,666 \%$ menyatakan setuju.

\section{SARAN}

Untuk meningkatkan kinerja serta menyempurnakan penelitian yang telah dibuat ini, maka peneliti memberikan saran pengembangan selanjutnya, sistem diharapkan dapat menerapkan alat selain Rich Internet Application (RIA).

\section{DAFTAR PUSTAKA}

[1] Wahyuningsih, Delpiah dan Yohanes Setiawan. Penerapan Teknologi Rich Internet Application pada Proses Tracer Alumni STMIK Atma Luhur Berbasis Website. Jurnal Edukasi dan Penelitian Informatika (JEPIN) Vol 2, No 2. 2016.

[2] Noviyanto, Fiftin dan Ahmad Ashari. Penerapan Teknologi RIA untuk Membangun Aplikasi Web dengan Pengaksesan Realtime. Jurnal Informatika Vol 5, No 12011.

[3] Djunaedi, Eggy Ramadhani. Konsep Rancang Bangun Aplikasi E-Traveling Berbasis Customer Relationship Management Menggunakan Rich Internet Application. Teknik Informatika. Universitas Islama Negeri Syarif Hidayatullah: Jakarta. 2011.

[4] Noviyanto, Fiftin dan Danang Dwi Wahyu Jati. Rich Internet Application (RIA) untuk Aplikasi Sistem Informasi Klinik Kesehatan. Jurnal Informatika Vol 3, No 2009.

[5] Imron, Mochamad Samsudin, dkk. Perancangan dan Implementasi Aplikasi Pembelajaran Siklus Carnot Berbasis RIA untuk Pelajar SMA. Jurnal Teknologi Informasi - Aiti, Vol 11 No 12014.

[6] Asri, Yessy dan Anggi Puspita Sari. Implementasi Teknologi RIA dalam Pengembangan Antar Muka Berbasis Web menggunakan EXT JS Frame Work. Jurnal Pengkajian dan Penerapan Teknik Informatika (PETIR) Vol 2, No 12009.

[7] Busch, Marianne dan Nora Koch. Rich Internet Application State of the Art. Institute for Informatics. Ludwig Maximilians Universitat Munchen Germany. 2009.

[8] Pressman, Roger S. Software Egineering: A Practitioner's Approach. Mc Graw Hill: Americas. 2001. 